\title{
CONTEXTUALISING ROMAN-RELATED GLASS ARTEFACTS IN CHINA. AN INTEGRATED APPROACH TO SINO-ROMAN RELATIONS
}

\author{
KRISZTINA HOPPÁL \\ Damjanich János Múzeum \\ Kossuth tér 4, Szolnok, H-5000, Hungary \\ hoppalkriszti85@gmail.com
}

\begin{abstract}
Relations between the Roman and the early Chinese Empires have been considerably popular fields of research, however, principally from a trade-oriented point of view. Contextualising Roman-related glass finds unearthed in the People's Republic of China provides a more complex nexus. Transparent glass vessels carry multiple testimonia of cultural impacts and interactions, leading towards a stereotyped and utopian perception of the Imperium Romanum.

This paper focuses on the complexity of such inter-imperial connections through contextualising the most significant Roman-interpreted glass finds in China. Furthermore, by a detailed and critical examination of Roman-related transparent glass vessels, it also aims to highlight problems of earlier identifications and interpretations. In addition, a precise recollection of the existing data not only allows to catalogue these various glass objects, but also helps to insert these glass artefacts into the Roman glass typology system.
\end{abstract}

Keywords: Sino-Roman relations; reception studies; glass artefacts; cross-cultural interactions

\section{ROMAN-RELATED GLASS ARTEFACTS IN CROSS-CULTURAL INTERACTIONS - AN INTRODUCTION}

Critical discourses on cross-cultural interactions and the interdisciplinary standpoint towards these dynamic interrelated systems play an important role in recent studies. ${ }^{1}$ The integrated comparison of Chinese and Roman perceptions serves as a significant element of such debates. Accordingly, the period of $1^{\text {st }}-5^{\text {th }}$ century constitutes the main body of the paper, when Daqin 大秦 appears as a multifold synonym of the Roman Empire in Chinese records, and also when Seres are presented as vague ethnonym of silk makers on the easternmost part of the Oikumene in Antique works. ${ }^{2}$ In this regard, the paper also aims to present a simple but reliable ground towards contextualizing the comparative perceptions of Rome and China (i.e. the Middle Empire) by using written sources and archaeological data as a complex system, in order to reveal new aspects of seeing and being seen. ${ }^{3}$

Through appropriate methods of investigation, it is possible to have a better understanding of the reception of "foreign" in China and Rome. Transparent glass vessels, western imported metalworks and decorated textiles in China; silk tapestries and hu bronzes in the Imperium Romanum carry multiple testimonia of cultural impacts and interactions, leading towards a stereotyped and utopian picture of the two imperii. This paper intends to focus on

\footnotetext{
${ }^{1}$ See e.g.: CANEPa 2010; CANEPa 2014. Other aspects e.g.: WOOLF 1994; HARDWICK 2003.

${ }^{2} \mathrm{~A}$ great number of studies have been published on this field. A few recent examples: YING 2004; KoRDOSES 2008; DE LA VAissiÈre 2009; von Walter 2011; Yu 2013; SeVILlano-LóPEZ 2015. For a more detailed bibliography: HoppáL 2015b.
}

${ }^{3}$ The paper is a part of the author's recently submitted, therefore unpublished dissertation 'Contextualizing the comparative perceptions of Rome and China through written sources and archaeological data' See Hoppal 2015b. For terms see CANEPA 2010. 7, 9. 
the complexity of such cross-imperial connections through contextualizing the most significant Roman-interpreted glass finds. The incorporation of archaeological remains into the complex, utopian and multileveled Daqin-tradition helps to understand local answers to the Non-Local. ${ }^{4}$

\section{MATERIALS, METHODS AND GOALS}

The chronological frame of the paper spans from the $1^{\text {st }}$ century to the $5^{\text {th }}$ century (although earlier and later sources were also analysed), from the appearance of the terms Daqin and Seres until the elementary changes of data in the $5^{\text {th }}-7^{\text {th }}$ century. The appendix contains eleven items interpreted as Roman (or in some cases Roman-like) in earlier studies. These objects were analysed in their complexity: social context, geographical and historical nexus. ${ }^{5}$ Due to the problems and limits of such comprehensive research - namely, the accessibility of archaeological remains discovered in the People's Republic of China - only published materials were used.

Although Roman-like transparent glass vessels unearthed in China are the most remarkable (both in number and relevance) group of archaeological finds - since original materials are hardly available - still many misinterpretations and misquotations exist in modern studies. In light of these problems, the catalogue of the most important items (see Appendix) is devoted to collect all the existing data to build a reliable, searchable and verifiable database, which might serve as a ground for later research.

Accordingly, as a basis, in later studies the presented approach might be able to help reveal problems such as:

1. What factors might play a role in forming perceptions of Rome and China, and how?

2. How ways of seeing and being seen could be described in context of China and Rome?

3. Is there any universality/common aspect in Roman and Chinese perceptions of each other?

4. How could the reception of "foreign" be depicted in context of the two imperii?

5. In light of complex approaches and methods, how could Sino-Roman relations be (re)described?

\section{GROUPING TANSPARENT GLASS VESSELS DISCOVERED IN THE EASTERN COASTAL PART OF CHINA}

As a result of the above mentioned attempt, four main groups of transparent glass vessels previously interpreted as Roman can be formed by date and localisation. ${ }^{6}$ These are the Ganquan Region, the Nanjing Region, the Northern or Later Group and the Xinjiang Region. Due to the limitations of this paper only the first two regions will be presented below. ${ }^{7}$ (Fig. 1)

\section{III.1. Ganquan Region}

Ganquan is situated in Jiangsu province, on the eastern coast of the People's Republic of China. Two burials containing Roman transparent glass vessels have been discovered (and published) so far: the Shuangshan and the Laohudun tombs. ${ }^{8}$ (Fig. 2)

In the Shuangshan tomb no. 2 small fragments of a purplish, marbled ribbed bowl were unearthed (see Appendix CAT.I.1.), while in the Laohudun burial a nearly intact bluish transparent cup was found (see Appendix CAT.1.2.). According to the chemical compositions of these vessels both of them are unquestionably Roman finds. ${ }^{9}$ Based on research by An Jiayao, the closest analogy of the Shuangshan bowl is in the collection of the British Museum. ${ }^{10}$ The intact purplish, marbled ribbed bowl was discovered in Jidd Hafs grave no. $36 .{ }^{11}$ Although

\footnotetext{
${ }^{4}$ Another example: Hoppál 2015a.

${ }^{5}$ However, regarding the limits of the paper, the summary of the analysis will be presented.

${ }^{6}$ However, a few individual finds could also be cited, such as the glass bottle from Luoyang. See AN 2004. 113.

${ }^{7}$ For detailed analysis of the Northern/Later Group see HopPÁL 2015b. Glass objects discovered in Xinjiang Region will be used for comparison.
}

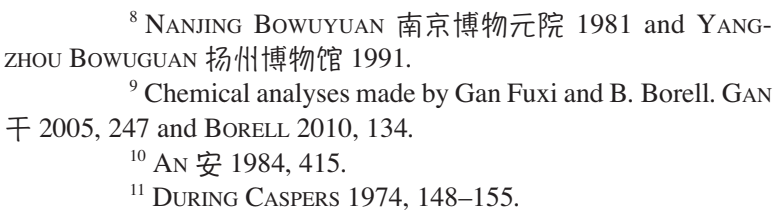

${ }^{8}$ NANJING BOWUYUAN 南京博物元院 1981 and YANGZHOU BOWUGUAN 扬州博物馆 1991.

${ }^{9}$ Chemical analyses made by Gan Fuxi and B. Borell. GAN 干 2005, 247 and BORELL 2010, 134

${ }^{10}$ AN 安 1984, 415.

${ }^{11}$ During CASPERS 1974, 148-155. 


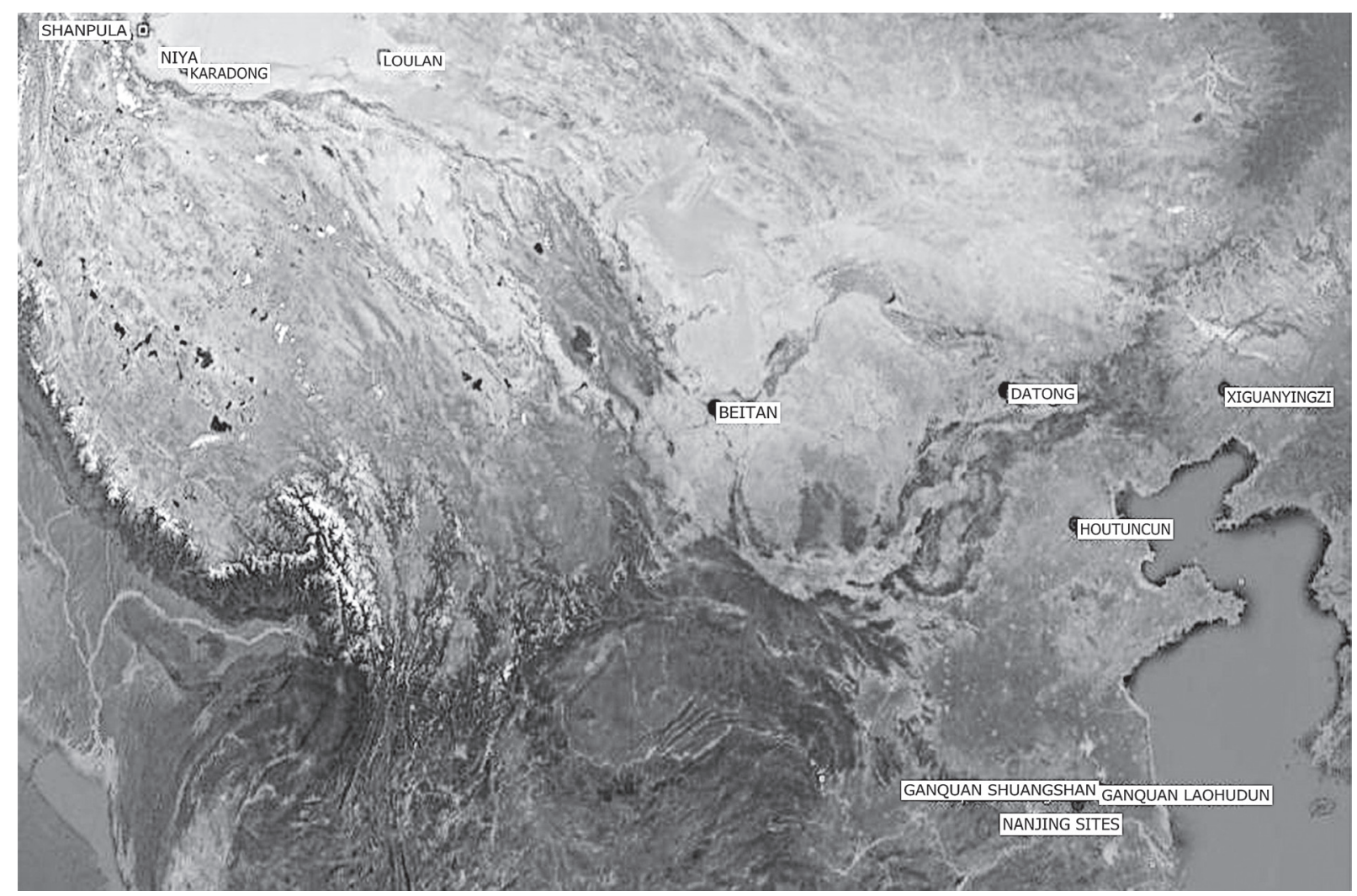

Fig. 1. Map of some Roman-related artefacts from the People's Republic of China (based on Google Earth)

marbled ribbed bowls in various colours were popular all over the Roman Empire, the purplish variation is considered to be less abundant. The earliest types could be dated as early as the $1^{\text {st }}$ century B.C., while by the second part of the $1^{\text {st }}$ century C.E. the production of these vessels ended. ${ }^{12}$

The Shuangshan tomb is widely accepted to be the burial of Guang Ling, ${ }^{13}$ the son of the Han Chinese emperor Guang Wudi. Soon after the death of Guang Wudi in 57 C.E., Guang Ling rebelled against his elder brother who became the new emperor. He was forced to commit suicide in 67 C.E. ${ }^{14}$ which date also serves as a terminus post quem of his tomb. official. ${ }^{15}$

Based on the excavation report, the Laohudun tomb has been interpreted as a burial of Guang Ling's high

To understand the significance of the relation between the Ganquan vessels and these influential members of the Chinese aristocracy, it is worth citing the Standard Histories such as the Hou Han shu. According to the passages describing the communication with Daqin the Protector-General Ban Chao sent an official envoy to Daqin lead by Gan Ying. ${ }^{16}$ Although the delegation never reached the Roman Empire, the fact that an official claim to discover that distant Empire existed is remarkable in itself. Nevertheless - as D.D. Gardiner and K. H. J. Leslie have pointed out - the Chinese aristocracy had to possess some vague information on the Romans to discover more ${ }^{17}$. Therefore - if we accept the above statements - it cannot be excluded that the Roman transparent glass vessels of Ganquan (dated before 97 C.E.), might have played a role in enquiring further knowledge on the country from which they came. However, it is more than difficult to find any relevant proof of such presumption.

${ }^{12}$ However in the western part of the Roman Empire the production has lasted until the $2^{\text {nd }}$ century C.E. STERN-SCHLICK-NOLTE 1994, 72-79.

${ }^{13}$ A seal with the inscription 'Guang Ling's official seal 广 陵王穻' was discovered in the tomb in 1981. NANJING BowUYUAN 南 京博物元院 1981, 9 .
${ }^{14}$ Hou Han shu xishierjuan Guangwu shiwangliezhuan di sanshier 後漢書四十二卷光武十王列傳第三十二

${ }^{15}$ YANGZHOU BowUGUAN 扬州博物馆 1991.

${ }^{16}$ Hou Han shu juanbashiba Xiyuzhuan diqishiba 後漢書卷八 十八西域傳第七十八. HIRTH 1885, 200; Yu 2013, 26-28, 33-41, 57-61.

${ }^{17}$ LesLie-Gardiner 1996, 141.

Acta Archaeologica Academiae Scientiarum Hungaricae 67, 2016 


\section{III.2. Nanjing Region}

The western-imported transparent glass vessels discovered in the Nanjing region constitute the second group. All these objects unearthed in tombs are dated to the period of the Eastern Jin dynasty (317-420 C.E.). These burials are situated in the Nanjing area which served as the capital of the Jins under the name Jiankang. During the reign of the Eastern Jin, powerful members of wealthy families controlled the empire, sometimes with a greater influence than the emperors and their families. ${ }^{18}$ Their graveyards all over Nanjing served as a memento of the competition of wealth and power. (Fig 3)

Under the above facts, the group of the Nanjing vessels is considered to be a well-defined area in both time and space and might therefore be suitable for comparing the social context of Roman and Sasanian glass objects discovered there.

As a first sub-division the transparent glass vessels previously interpreted as Roman will be presented. ${ }^{19}$ (Fig. 2)

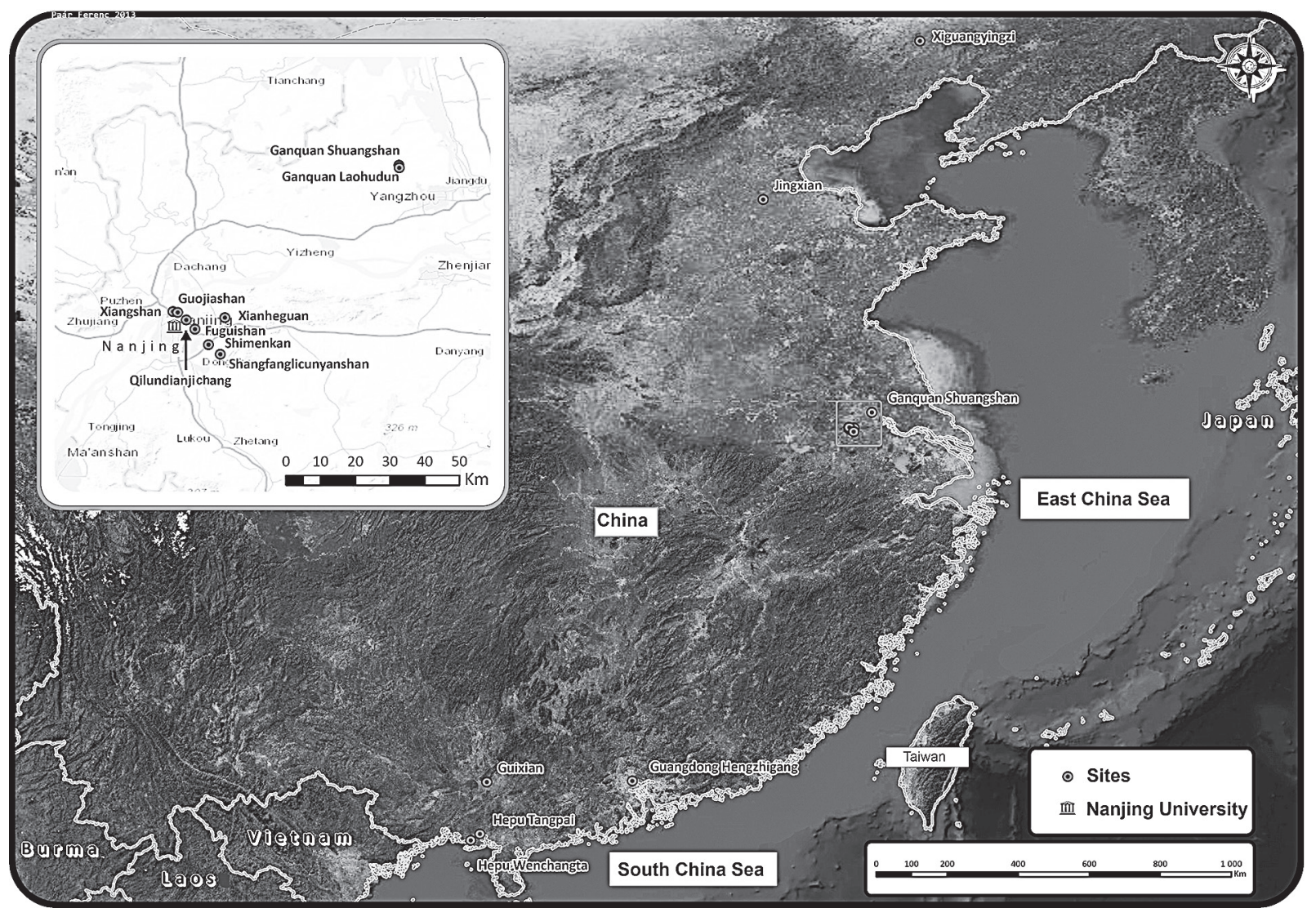

Fig. 2. Map of some Roman-related and western influenced glass artefacts in the eastern coastal part of People's Republic of China (by Ferenc Paár)

Altogether four tombs containing glass vessels were previously identified as Roman objects: the Qilundianjichang tomb no. 2 (see Appendix CAT.II.1.1-2.), the Nanjing University Northern Campus burial (see Appendix CAT.II.2.), the Xiangshan grave no. 7 (see Appendix CAT.II.4.1-2.) and the Shimenkan tomb (see Appendix CAT. II.3.). However, due to the scant documentation of the latter - since it was published in 1958 - no eligible information on its glass shards exists. ${ }^{20}$

\footnotetext{
${ }^{18}$ HuA 华 2003, 283.

${ }^{20} \mathrm{LI}$ 李-TU 屠 1958, 66.

${ }^{19}$ By An Jiayao, Gan Fuxi and Wang Zhigao. An 安 1984, 444; GAN 干 2005, 246-252; WANG 王 2011, 221-223.
}

Acta Archaeologica Academiae Scientiarum Hungaricae 67, 2016 


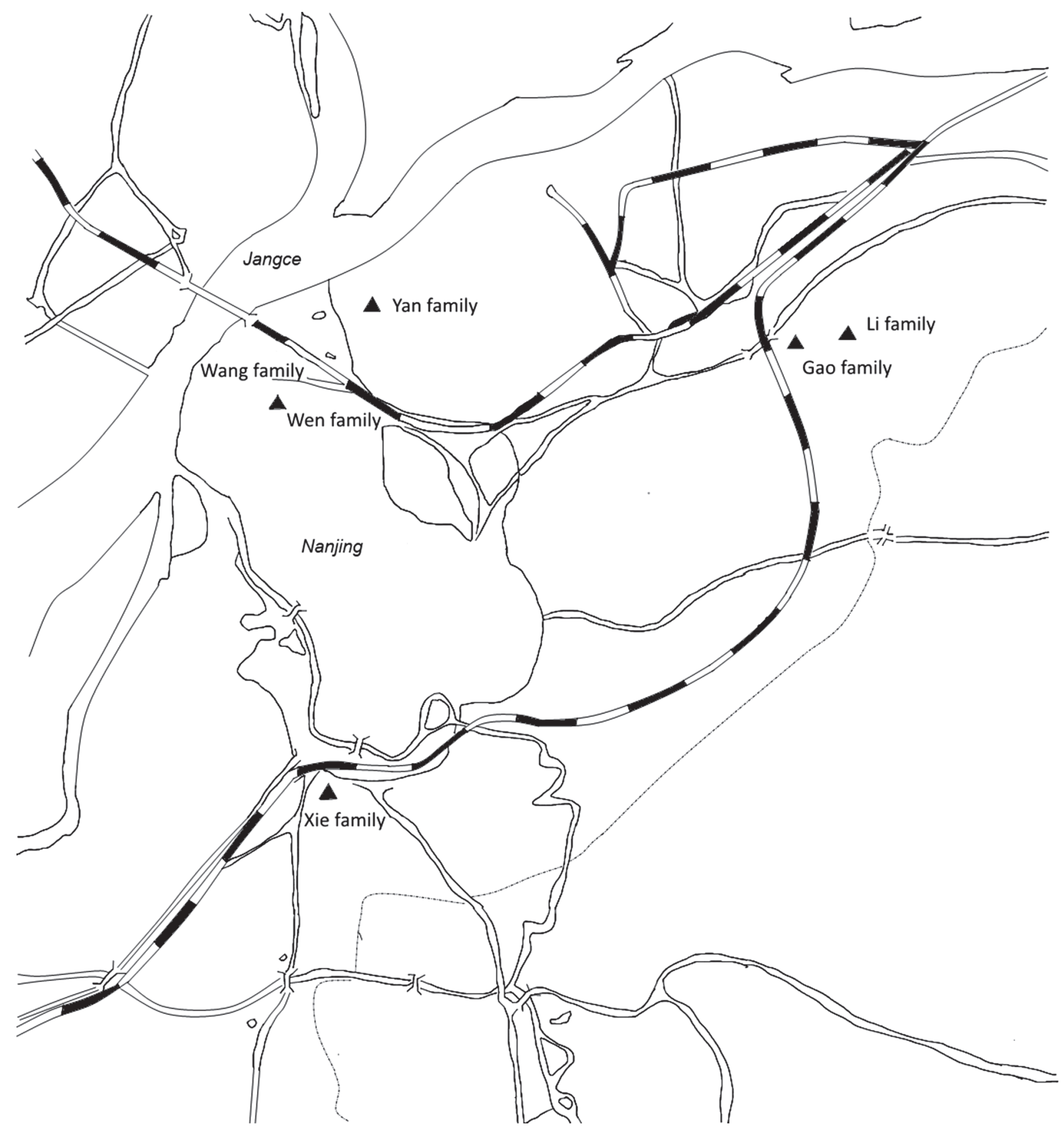

Fig. 3. Burials of wealthy families in Nanjing (based on HuA 华 2003)

Moreover, only the chemical compositions of the yellowish and bluish glass fragments from the Qilundianqichang burial no. 2 are published. ${ }^{21}$ Based on the chemical analyses the two vessels presumably originated in the Roman Empire. Nevertheless, in the case of the glass objects discovered in Xiangshan and the Nanjing University ${ }^{22}$ - due to the absence of chemical compositions - it is more complicated to take a side.

${ }^{21}$ NANJing BowUGUan 南京博馆 1983, 321-322.

${ }^{22}$ For the excavation report of the Xiangshan and Nanjing University vessels see: NANJINGSHI BOWUGUAN 南京市博物馆 1972 and NANUING DAXUE LISHIXI KAOGUZU 南京大学历史系考古组 1973. Illustration: NANJING BowUGUAN 南京博物馆 2004, 42, 43. 


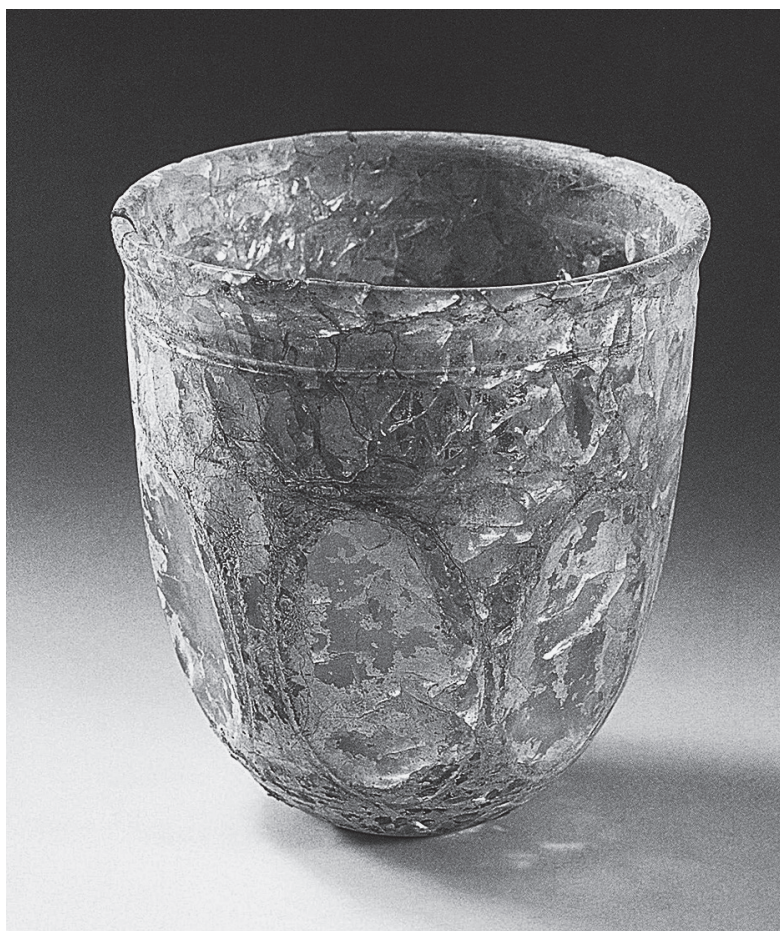

Fig. 4. Glass cup discovered in Xiangshan

(NANJING BOWUGUAN 南京博物馆 2004, 96)

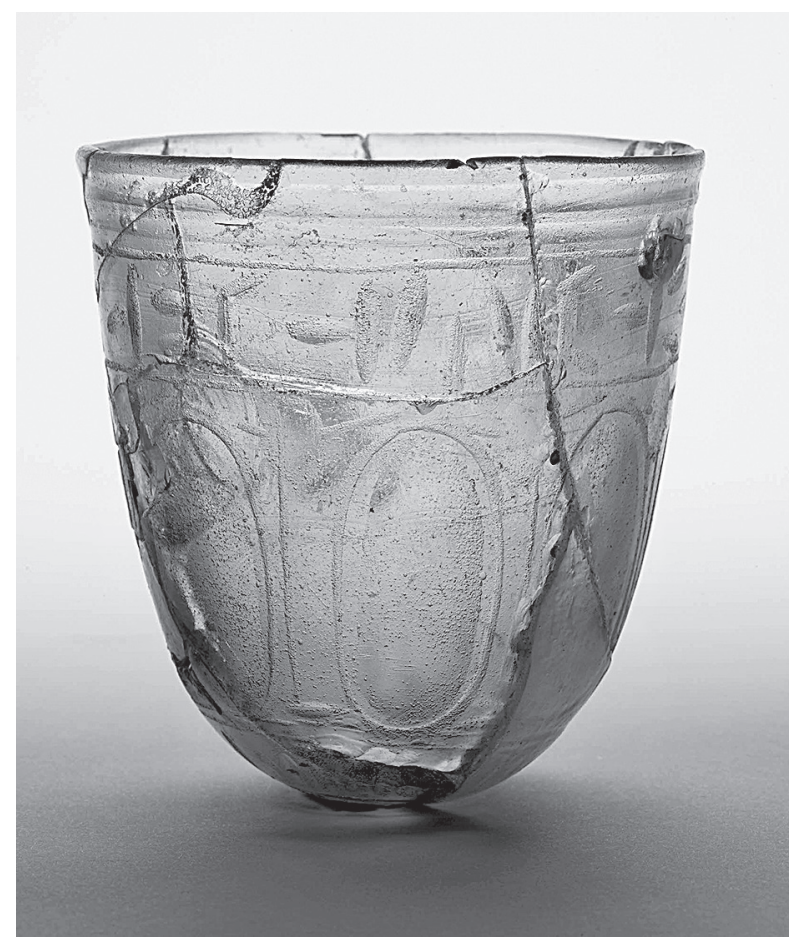

Fig. 5. Glass cup from Amlash (C)Trustees of the British Museum

The characteristics of the faceted glass fragments discovered in the Northern Campus of the Nanjing University are close to the Roman style. ${ }^{23}$

The interpretation of the Xiangshan glass cup is considered to be more problematic, since the form and decoration of the object are close to the Sasanian design. Moreover, its closest analogy in the collection of the British Museum is undoubtedly Sasanian as well. ${ }^{24}$ (Figs 4-5)

For the above reasons it might be assumed that the Xiangshan cup is Sasanian rather than Roman.

Apart from the problems of interpretation of the vessels presented above, their social context seems to be less complicated. Among these burials, tombs of the Eastern Jin emperors and their relatives and high officials closely related to the ruling family can be found. (see Appendix CAT.II.)

In the second subdivision of the Nanjing group (Fig. 2) the transparent glass vessels previously interpreted as Sasanian will be displayed $:^{25}$ an intact bluish spherical bowl from the Fuguishan tomb no. 4 (see Appendix CAT. II.5.) and an intact faceted bowl from the Xianheguan tomb no. 6 (see Appendix CAT.II.6.). ${ }^{26}$ However, in an absence of chemical analyses it is more problematic to identify the origin of these transparent glass objects. Since the very common form of the Fuguishan bowl was popular in both of the two empires - by using morphological and chronological methods alone - it is difficult to define its origin. (Fig. 6)

${ }^{23}$ For the Sasanian style see GOLDSTEIN 2005, 51. However, the slight differences between the characteristics of the Sasanian and Roman glass wares are not sufficient to specify the origin of the Nanjing University vessel. More details on these difficulties: MEREDITHGOYMOUR 2006, 124-126.

${ }^{24}$ http://www.britishmuseum.org/research/search_the_collection_database/search_object_details.aspx?objectid=367254\&parti $\mathrm{d}=1 \&$ searchText $=$ cut + glass $\&$ fromDate $=100 \&$ fromADBC $=$ ad \& toDat $\mathrm{e}=400 \&$ to $\mathrm{ADBC}=\mathrm{ad} \&$ numpages $=10$ \&images $=$ on \&orig $=\% 2$ fresearch $\% 2$ fsearch_the_collection_database.aspx $\&$ currentPage $=6$ [accessed: 15.02.2015]

Acta Archaeologica Academiae Scientiarum Hungaricae 67, 2016
${ }^{25}$ However, presumably western-imported glass objects were discovered in two more burials - Guojiashan tomb no. 13 and the unpublished grave of Shangfanglicunyanshan - because of fragmentation/scanty documentation it is difficult to define their origin. Nevertheless their social context considered to be very similar to the vessels of the Nanjing group. See: NANJINGSH IBowUGUAN 南京市博物馆 2008; WANG 王 2011, 221-223.

${ }^{26}$ NANJINGSH BowUGUAN 南京市博物馆-NANJINGSHI XUANWUQU WeNHUAJU 南京市玄武区文化局 1998; NANJING BOWUGUAN 南京博物馆 2001 . 


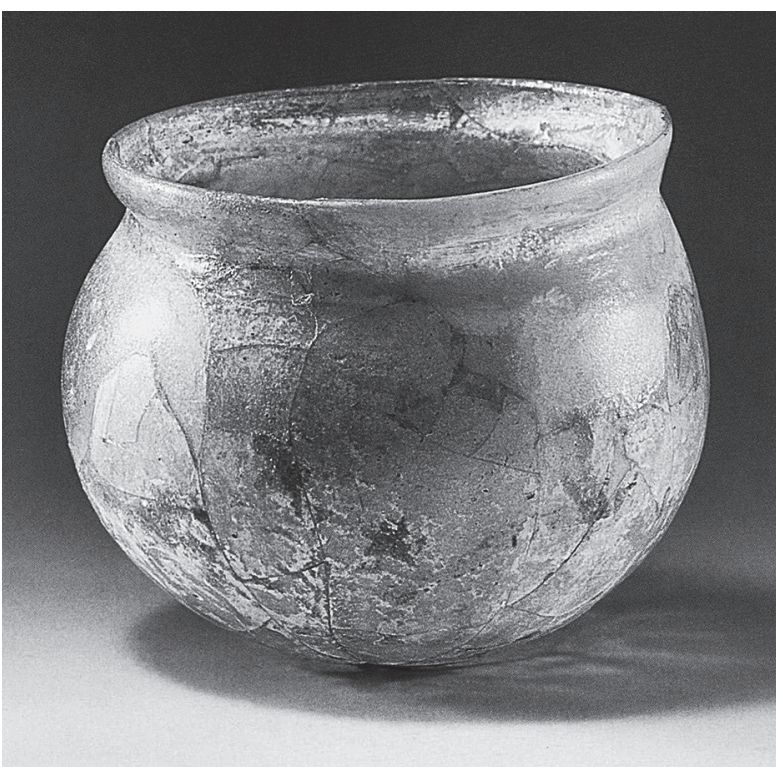

Fig. 6. Glass bowl discovered in Fuguishan (NANJING BowUGUAN 南京博物馆 2004, 42)

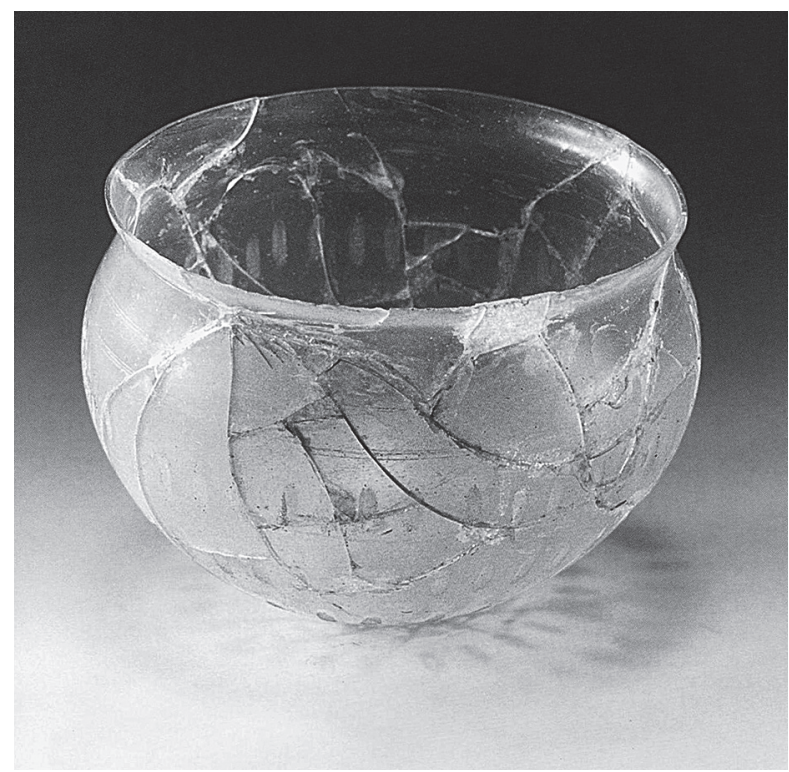

Fig. 7. Faceted glass bowl discovered in Xianheguan Faceted glass bowl discovered in Xianheguan

(NANJING BowUGUAN 南京博物馆 2004, 43)

Moreover, the pattern of the Xianheguan bowl (formed by vertical and horizontal oval facets and lines) is considered to be more popular in the Roman than the Sasanian Empire. (Fig. 7) A close analogy was discovered in Karanis (Roman Egypt) dating to the second half of the $2^{\text {nd }}$ century. ${ }^{27}$

Nevertheless, the social context of the above bowls is similar to the social background of vessels in the first subdivision: the Fuguishan grave no. 4 is accepted as belonging to the ruling family ${ }^{28}$ and the Xianheguan bowl was unearthed in the burial of a high ranking official closely related to the Eastern Jin emperor. ${ }^{29}$ (see Appendix CAT.II.)

Under the above considerations, no difference between the social context of the Roman and Sasanian glass vessels in the Nanjing region seems to be displayed. Therefore it might be assumed that the ancient Chinese aristocracy was not capable of distinguishing the Sasanian and Roman vessels from each other - or, more likely, the objects presented above might have had the same importance.

\section{CONTEXTUALIZING TRANSPARENT GLASS VESSELS DISCOVERED IN THE EASTERN COASTAL PART OF CHINA}

The social status of the presented burials in China is equally high regardless of the true origin of the vessels i.e. being Roman or Sasanian. The undoubtedly Roman vessels unearthed in Ganquan region were identified to belong to Guang Ling - son of the Han emperor - and his official. At the same time, bowls in the Nanjing area are connected to the Eastern Jin emperors or members of his family i.e. the Simas, high officials and private ministers (personal acquaintances of the emperors). Consequently all these imported objects were discovered in the burials of emperors and their closest men: a well-defined and limited stratum of Chinese aristocracy, with not only considerable wealth but prestige as well.

It is also important to take into account that none of the presented glass vessels - regardless of their place of origin is the Roman or the Sasanian Empire - can be regarded as unique or highly artistic items. ${ }^{30}$ All of these bowls and cups from the Ganquan and Nanjing Regions are well known forms of Western glass manufacture being produced in a great quantity. ${ }^{31}$

\footnotetext{
${ }^{27}$ HARDEN 1936, 31, 120.

${ }^{28}$ NANJingshi BowUGUan 南京市博物馆-NANJINGSHI XUANWUQu Wenhuaju 南京市糸武区文化局 1998, 47.

${ }^{29}$ NANIING BowUGUAN 南京博物馆 2001, 40
}

${ }^{30}$ Only exception is the duck shaped glass from the Northern group. See: LI 黎 1973; KINOSHITA 2009. 253-254; HoPPÁL 2015b.

${ }^{31}$ Number of analogies can be found e. g. in WHITEHOUSE 1997, 2001, 2001 and 2005. For more details: HoppáL 2015b. 
A careful study on the philological context of the transparent glass vessels might also help to have a deeper understanding on the significance of these items.

Besides historical records, references of transparent glass vessels appear in poems, discourses, biographies and other literary sources. ${ }^{32}$

The common feature of these contemporary sources is that in case the exact name of the place where these objects were produced is defined, the term Daqin ${ }^{33}$ or a place connected to Daqin (such as Liusha) ${ }^{34}$ is often used.

At the same time, according to the Shishuo Xinyu [A new account of tales of the world] dated to the $5^{\text {th }}$ century C.E., the worth of the transparent glass vessel lays on its transparency. ${ }^{35}$ It is worth comparing the above passages with the words of Pliny the Elder. The Natural History says: 'maximus tamen honos in candido tralucentibus, quam proxima crystalli similitudine ${ }^{36}$

Another important detail to the value of the transparent glass vessels is given in a poem by Fu Xian, dated to the $3^{\text {rd }}$ century C.E. According to the Wu zhi fu [Fu on a dirty zhi] after the highly treasured transparent glass cup became dirty it lost its value, since it could not be cleaned. Although the above passages could be interpreted as a topos, one might also assume that the vast majority of Chinese were confused by glass as a material.

Concluding the explanations given by literary sources the transparent glass vessels were treasured because of their transparency and curiosity and mostly they originated in the Western Lands - according to some more specific records, in Daqin.

It is well known that these western-imported objects were rare and precious since they came from distant places - as An Jiayao has pointed out. Moreover, the archaeological evidence shows that the technique of glassblowing was unknown in China, presumably until the $6^{\text {th }}$ century. ${ }^{37}$ Nevertheless, as the description of the glass production of the Nan Yue people in the Baopuzi ${ }^{38}$ also assumes, this method of glass making was misunderstood by Chinese society ${ }^{39}$ Under above considerations the importance of the transparent glass objects - besides their rarity - might be explained with other aspects such as the mysterious way of their production.

An Jiayao has also stated that the glass was believed to be a simulation of jade..$^{40}$ Therefore, as a jade-like material (regardless of how accurate the imitation could be), the transparent glass vessels might have had a ritual aspect as well.

It is noteworthy that a great number of the presented burials were robbed - e.g. the Ganquan Shuangshan tomb ${ }^{41}$ - although despite the act of plunder, transparent glass vessels of these graves remained untouched.

Synthesizing the above presented experiences on the role of these items in Chinese society, their value might have consisted of three different elements:

1. their rarity and the distance - limited accessibility/hardly attainable,

2. the misunderstanding of their production and the lack of glass blowing and artistic decorating technique being impossible to reuse/reprocess and resell,

3. significance in ritual life (presumably similar to jade), being owned by a group with the highest status.

These observations might lead into the concept of immaterial worth: transparent glass vessels might be rare prestige objects, belongings of the highborn, with value beyond the material and the financial.

\footnotetext{
${ }^{32}$ A great summary is displayed by An Jiayao. See AN $2002,56-59$

${ }^{33}$ Besides the historical record the Xuanzhongji 糸中記 (by the famous taoist scholar, Guo Pu 郭理) describes the five-coloured glass of Daqin. BoRELL 2010, 128.

${ }^{34}$ Liusha 流沙 appears in the poem 'Liuli wan fu 琉璃碗 赋 [Fu on a glass bowl]' by Pan Ni 潘尼 (250?-311? C. E.). In: Yiwenleijuqishisan you bashisi 藝文類聚七十三又ハ十四 AN 2002, 57.

${ }^{35} \mathrm{In}$ : Shishuoxinyu paidiaopiandiershiwu 世說新語排调 篇第二十五 An 2002, 56 .
}

\author{
${ }^{36}$ Plinius Naturalis Historia XXXVI, 198. English transla- \\ tion: http://www.perseus.tufts.edu/hopper/text?doc=Perseus\%3Atext \\ \%3A1999.02.0137\%3Abook\%3D36\%3Achapter\%3D67 [accessed \\ 15.02.2015.] \\ ${ }^{37}$ Although other methods of glass production were known \\ AN 2002, 56, 47 . \\ 38 'The master who embraces simplicity' written by the \\ famous taoist philosopher, Ge Hong 葛洪 (283?/284?-343). \\ ${ }^{39}$ Ge Hong Baopuzi neipianjuanerlunxian 葛洪抱朴子内 \\ 篇卷二論仙. AN 2002, 46 . \\ ${ }^{40}$ AN 2004, 58 \\ ${ }^{41}$ See: NANJING BowUGUan 南京博物元院 1981.
}




\section{CONTEXTUALIZING WESTERN IMPORTED GLASS VESSELS FROM XINJIANG - A COMPARISON}

Roman (and Roman-influenced) glass finds discovered in Xinjiang-Uyghur Autonomous Region, regarding the cultural-ethnical diversity of the area, are divided into a separate group. ${ }^{42}$ As a consequence of the above mentioned particularities, Roman-related artefacts (not only western imported glass vessels but other materials as well) from this region might not have had direct impact on formulating perceptions of Daqin in Han-Chinese society. In this case, these Roman-related objects play an indirect role in affecting Chinese perceptions of the Roman Empire. Although these items might also help to have a deeper understanding on the various and complex artistic/ cultural models of the Silk Road, ${ }^{43}$ in light of these difficulties only transparent glass vessels that underwent chemical composition analyses will be observed. ${ }^{44}$ (Fig. 1)

Furthermore, it must also be stated that despite the increasing number of carefully investigated glass objects from Xinjiang, in several cases find-context was not/or could not be registered. Under such circumstances, only a few examples can be used for comparison.

One of these is a faceted glass shred from Loulan. (Fig. 8) The whitish fragment of a transparent glass cup was not discovered in a cemetery but in a settlement section (see Appendix CAT.III.1.) ${ }^{45}$ Another type of Roman glasses in Xinjiang is a blue eye bead (No. 84HLSM49:155L) unearthed in Shanpula cemetery no. I. ${ }^{46}$ The blue, ring shaped object being a part of a necklace of orange beads ${ }^{47}$ was unearthed in a burial of sixteen bodies (see $A p$ pendix CAT.III.2.). Although the excavation report does not offer details of the exact find-context, basic information on grave goods is available. According to the report the burial of sixteen bodies contained simple potteries, textiles and implements: nothing comparable with tombs of the Eastern Coast. ${ }^{48}$

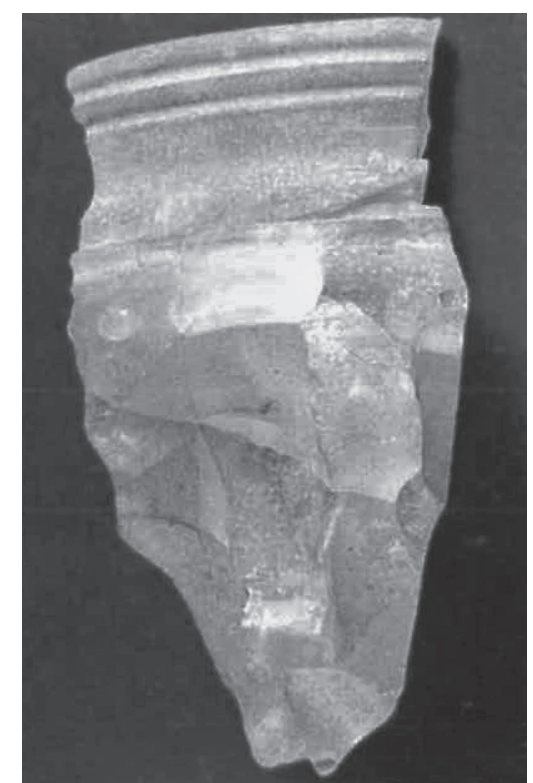

Fig. 8. Fragment of a faceted glass cup from Loulan (YU 2010, 191)

\footnotetext{
${ }^{42}$ Important works on this matter e. g.: Di Cosmo 2000; YU 2004; MilLWARD 2007; YÜ 2008. etc.

${ }^{43}$ E. g.: Lin 林 1998, 2003, 2006; HANSEN 2012; BRown 2014.

${ }^{44}$ E.g. JianZhu CaIliao YanjiUyUan Qinghua DaXue 建 筑材料研究院清华大学-ZHONGGUO SHEHUIKEXUEYUAN KAOGUYANJIUSUO 中国社会科学院考古研究所 1984; BRILL 1999; 2007. etc.

${ }^{45}$ The exact localisation was not documented, the shortexcavation report only informs it was discovered near the settlement
}

section, from an area called C. See: XINJIANG Loulan KaOgudu 新 疆楼兰考古队 1988, 6; LI 李-GAN 干-ZHANG 张 2007, 153, 166.

${ }^{46}$ LI 李-GAN 干-ZHANG 张 2007, 153; 166.

${ }^{47}$ WANG-LU 2009, 319.

${ }^{48}$ XINJIANG WeWUERZIZHIQU BowUGUAN 新疆维吾尔自 治区博物馆-XINJIANG WENWU KAOGU YANJIUSUO 新疆文物考古研 究所 2001, 9-11.

Acta Archaeologica Academiae Scientiarum Hungaricae 67, 2016 
Since the 'Western Regions' or Xiyu 西域 - as it was called in Chinese chronicles - can be considered as politically and ethnically complex area, it is not surprising that the social background of the above presented discoveries is very different from ones in the eastern coastal part of China.

\section{CONTEXTUALIZING ROMAN-RELATED GLASS ARTEFACTS - A CONCLUSION}

Analysing the social and philological context of western-imported transparent glass vessels, the first step is to treat the information carefully enough. Although the above mentioned glass objects are considered to be the most significant group of archaeological finds connected to the Roman Empire, in absence of chemical analyses it is complicated to determine their origin. The glass production of the Roman and Sasanian Empires had several similarities - especially the group of faceted vessels. ${ }^{49}$ Since many similar forms and decoration designs had flourished by using morphological methods alone it is difficult to distinguish the different workshops and characteristics.

Nevertheless, the social status of the presented burials in the eastern coastal part of China is equally high: transparent glass vessels of the Ganquan and the Nanjing group( also from the Northern group) were discovered in burials of a well-defined and limited stratum of Chinese aristocracy, with not only considerable wealth but prestige as well. According to the literary sources they were exotic, rare, jade-lake materials, although in their place of origin i.e. the Roman or the Sasanian Empire they can be regarded as common items of glass manufacture. They might be treasured because of their curiosity and mysterious and ritual characteristics. Therefore it is also probable that it was a matter of course to identify the origin of these mythical products as a mythical and utopian place, called Daqin.

At the same time, the number and background ${ }^{50}$ of glass objects from Xinjiang Region - because of differing culturally and ethnically from the eastern areas of China- presumes a different context: a more material value of these finds.

Summing up the significant information obtained from Roman-related archaeological data, the following perceptions of the Roman Empire can be outlined:

1. distant: its products are moved by a series of middlemen as a long-term (in some cases hundreds of years) action, which results in an increasing material value, ${ }^{51}$

2. mystical: manufacturer of goods, often connected to ritual practice in Chinese society, which results in an increasing immaterial value of its products.

The above mentioned perceptions are adding new aspects towards the multileveled, utopian and mystical image of the Roman Empire.

\section{FUTURE RESEARCH}

Since this paper can be regarded as only a tiny part of a much bigger scale, further multidisciplinary approaches would be essential.

In this manner, the comparative reception of the two Imperii might serve as an interdisciplinary approach towards the problem of seeing and being seen. Another significant viewpoint might be a study of various responses to "foreign" in Chinese and Roman society, by using the archaeological data. Not only transparent glass vessels but silk remains too might be considered as possible forms of selection, evaluation, appropriation etc. The temporal and spatial patterns of perceptions - as significant elements of a complex mechanism - might be studied and form another important viewpoint of future research..$^{52}$

Moreover, developing a deeper understanding on factors of cross-cultural interactions and perceptions, critical debates on mediator cultures, peripheries and temporal cultural situations, or on eligibility of world-system theories would be important - taking limits and boundaries into account.

${ }^{49}$ For Roman faceted glass production see e.g.: STERN 2001, 137; To Sasanians: Whitehouse 2005, 41.

${ }^{50}$ Although in many cases reliable information on their find-contexts are hardly available.
${ }^{51}$ An accurate example is the duck shaped glass from $\mathrm{Xi}$ guanyingzi of the Northern Group. See Hoppál 2015b.

${ }^{52}$ The aforementioned aspects have been studied in the author's dissertation. 
Hybridization - especially in context of Xinjiang - and application of complex network analysis - as used in context of the Byzantine and Tang Empires - might also play an important role in future studies. ${ }^{53}$

Considering the current limits of research (problems on accessibility, documentation, determination of provenance, etc.), a demanding and multileveled discourse through an interdisciplinary research project is required.

\section{REFERENCES}

\section{AN 安 1984}

AN 2002

AN 2004

BORELL 2010

BRILL 1999

BRILL 2007

BROWN 2014

CANEPA 2010

CANEPA 2014

Di Cosmo 2000

DURING CASPERS 1974

GAN 干 2005

GAN 干 2007

GOETHERT-PolascheK 1977

GOLDSTEIN 2005

HANSEN 2012

HARDEN 1936

HARDWICK 2003

HIRTH 1885

HoPPÁL 2015a

HOPPÁL 2015b
= 安家瑶 AN Jiayao: 中国的早期玻璃器血 Early glass vessels in China. 考古学报 Kaogu Xuebao 4 (1984) 414-447.

$=$ J. AN: Glass vessels and ornaments of the Wei, Jin and Northern Dynasties. In: C. Braghin (ed.): Chinese Glass: Archaeological Studies on the Uses and Social Context of Glass Artefacts from the Warring States to the Northern Song Period. Firenze 2002, 45-70.

= J. An: The art of glass along the Silk Road. In: J. C. Watt (ed.): China. Dawn of a Golden Age, 200-700 AD. New York 2004, 57-66.

= B. BorEll: East and Southeast Asia. Trade and glass vessels along the Maritime Silk Road. In: by B. Zorn - A. Hilgner (eds): Glass along the Silk Road from 200 BC to AD 1000. RGZM-Tagungen 9. Mainz 2010, 127-142.

= R. H. BRILl: Chemical Analyses of Early Glasses, Vol. 1: Catalogue of Samples. New York 1999.

$=$ R. H. BRILL: 抛砖引玉-- 2005 年上海国际玻璃考古丝䀦之路玻璃专题研讨会开幕词Paozhuanyinyu---2005 nian Shanghai Guoji Boliqi Kaogu Sichouzhilu Boli Zhuanti Yantaohui Kaimuci. In 干 福喜 Gan Fuxi (ed.), 丝涠之路上的古代玻璃研究 Study on ancient Glass along the Silk Road 2004 年乌鲁木齐中国北方古玻璃研讨会和 2005 年上海国际玻璃考古研讨会论文集. Proceedings of 2004 Urumqi Symposium on Ancient Glass in Northern China and 2005 Shanghai International Workshop of Archaeology of Glass. 上海 Shanghai 2007, 30-43.

= P. Brown: The Silk Road in Late Antiquity. In: V. H. Mair - J. Hickman (eds): Reconfiguring the Silk Road: New Research on East-West Exchange in Antiquity. Philadelphia 2014, 15-22.

$=$ M. P. CANEPA: Theorising cross-cultural interaction among ancient and early medieval visual cultures. AA 38 (2010) 7-29.

= M. P. CANEPA: Textiles and elite tastes between the Mediterranean, Iran and Asia at the end of Antiquity. In: M-L. Nosch-F. Zhao-L. Varadarajan (eds): Global Textile Encounters. Ancient Textile Series 20. Oxford and Havertown 2014, 1-15.

$=$ N. Di Cosmo: Ancient city states in the Tarim Basin. In: M. H. Hansen (ed.): A Comparative Study of Thirty City-State Cultures. Copenhagen 2000, 393-407.

= E. C. L. During CASPERs: The Bahrain tumuli. Persica 6 (1974) 131-156.

=干福喜 GAN FuXI: 经涠之路促进中国古代玻璃技术的发展 Sichou zhi Lu Cujin Zhongguo Gudai Boli Jishu de Fazhan. In: 干福喜 Gan, Fuxi (著 zhu), 中国古代玻璃技术的发展 Zhongguo Gudai Boli Jishu de Fazhan. 上海 Shanghai 2005, 246-252.

= 干福喜 GAN FuXI: '丝涠之路上的古代玻璃研究 Study on Ancient Glass along the Silk Road' 2004 年乌鲁木齐中国北方古玻璃研讨会和 2005 年上海国际玻璃考古研讨会论文集. Proceedings of 2004 Urumqi Symposium on Ancient Glass in Northern China and 2005 Shanghai International Workshop of Archaeology of Glass. 上海 Shanghai 2007.

= K. Goethert-PolascheK: Katalog der Römischen Gläser der Rheinischen Landesmuseum Trier. Trierer Grabungen und Forschungen 9. Mainz 1977.

= S. M. Goldstein: Glass from Sasanian antecedents to European Imitations. London 2005.

= V. HANSEN: The New Silk Road. Oxford 2012.

= D. B. HARDEN: Roman Glass from Karanis. Found by the University of Michigan Archaeological Expedition in Egypt 1924-29. Ann Harbour 1936.

= L. HARDwick: Reception Studies. Greece \& Rome. New Surveys in the Classics 33. Oxford 2003.

= F. HiRTH: China and the Roman Orient. Researches into their Ancient and Mediaeval Relations as Represented in Old Chinese Records. Hong Kong 1885.

$=$ K. Hoppál: Daqin and the Luminous Religion from Daqin - the Nestorian stele of Xian. New aspects to the Chinese reception of the West. Tisicum XXIII (2014/2015) 327-332. [in Hungarian with English abstract]

= K. Hoppál: Contextualizing the comparative perceptions of Rome and China through written sources and archaeological data. [PhD dissertation in Hungarian with English abstract]

${ }^{53}$ Important studies e. g.: SelbitschKa 2010; Preiser-

KAPELLER 2014 and 2015. 
HuA 华 2003

ISINGS 1957

JIANZHU CAILIAO YANJIUYUAN QINGHUA

DAXUE 建筑材料研究院清华大学一

ZHONGGUO SHEHUIKEXUEYUAN

KAOGUYANJIUSUO

中国社会科学院考古研究所 1984

KINOSHITA 2009

KoRDOSES 2008

LESLIE-GARDINER 1996

LI 黎 1973

LI 李-TU 屠 1958

LI 李-GAN 干-ZHANG 张 2007

LIN 林 1998

LIN 林 2003

LIN 林 2006

Meredith-Goymour 2006

Millward 2007

NANJING BowUGUAN 南京博物馆 1983 = 南京博物馆 NANJING BowUGUAN: 南京北郊东晋墓发掘简报 Nanjing Beijiao Dong Jin mu fajue Jianbao. 考古 Kaogu 4 (1983) 315-322.

NANJING BowUGUAN 南京博物馆 2001 = 南京博物馆 NANJING BowUGUAN: 江苏南京仙鹤观东晋墓 Jiangsu Nanjingshi Xianheguan Dong Jin mu. 文物 Wenwu 3 (2001) 5-91

NANJing BowUguan 南京博物馆 2004 = 南京博物馆 NANJING BowUguAN: 六朝风采 Liuchao Fengcai. The Six Dynasties: A Time of Spelendor. 北京 Beijing 2004.

NANJING BOWUYUAN 南京博物元院 1981 = 南京博物院 NANJING, BowUYUAN: 江苏邗江甘泉二号汉墓 Jiangsu Hanjiang Ganquan Erhao Hanmu. 文物Wenwu 11 (1981) 1-10.

NANJINGSHI BowUGUAN

南京市博物馆 1972

NANJINGSHI BOWUGUAN

南京市博物馆 2008

NANJINGSHI BOWUGUAN 南京市博物馆-

NANJingshi XuANWUQU WenhuaJu

南京市玄武区文化局 1998

= 华国榮 HuA GuORONG: 南京六朝的王氏，谢氏高氏墓葬 The Eastern Jin tombs of the Wang, Xie, Gao famillies Near Nanjing. In: 巫鸿 Wu Hong (者 zhu), 汉唐之间礼学文化与物质文化 Between Han and Tang. Visual and Material Culture in a Transformative Period. 北京 Beijing 2003. = C. Isings: Roman Glass from Dated Finds. Archaeologica Traiectina 2. Groningen 1957.

= 建筑材料研究院清华大学JIANZHU CAILIAO YANJIUYUAN QINGHUA DAXUE 中国社会科学院考古 研究所 ZHONGGUO SHEHUIKEXUEYUAN KAOGUYANJIUSUO: 中国早期玻璃器检验报告 Zhongguo Zaoqi Boliqi Jianyan Baogao. 考古学报 Kaogu Xuebao 4 (1984) 449-457.

KinOshitA: Foreign glass excavated in China from the 4th to 12th centuries In: $M$. Mundell ( St. John's

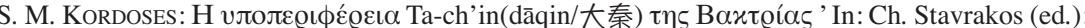

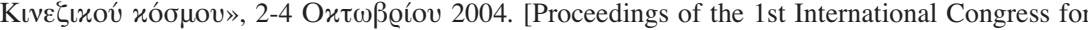
Sino-Greek Studies, "Re

= D. D. LeSLIE-K. H. J. GARdineR: The Roman Empire in Chinese Sources. Roma 1996.

= 黎瑶渤 LI YAOBO: 辽宁北票县西官营子北燕冯索弗墓 Liaoning Beipiaoxian xiguanyingzi Beiyan Feng Suofumu. 文物 Wenwu 3 (1973) 2-19.

Liuchaomu Jingliji. 考古通讯 Kaogutongxun 9 (1958) 69-67.

= 李青会 LI QINGHUI-干福喜 GAN FUXI-张平 ZHANG PING et al.: 新疆不同历史时期玻璃器的化 学成分分折报告 Xinjiang butonglishishiqi Boliqide Huaxuechengfenfenzhe Baogao. In: 干福喜 Gan Fuxi (ed.), 先䀦之路上的古代玻璃研究 Study on Ancient Glass along the Silk Road 2004 年 乌鲁木齐中国北方古玻璃研讨会和 2005 年上海国际玻璃考古研讨会论文集. Proceedings of 2004 Urumqi Symposium on Ancient Glass in Northern China and 2005 Shanghai International Workshop of Archaeology of Glass. 上海 Shanghai 2007, 151-168.

= 林梅村Lin MEICUN: 汉唐西域与中国文明 Han-Tang Xiyu yu Zhongguo Wenming. 北京 Beijing 1998

= 林梅村 LiN MeICUN: 汉代西域艺术中的希腊文化因素 Handai Xiyu Yishuzhongde Xilawenhua Yinsu. In: 郑培凯 Zheng Peikai (ed.), 九州学林 Jiuzhouxuelin 1.2 (2003) 2-35.

= 林梅村 Lin MeICUN: 经涠之路考古十五讲 Sichouzhilu kaogu shiwu jiang. 北京 Beijing 2006.

$=$ H. Meredith-Goymour: Disentangling material cultures: Late Roman and Sasanian facet cut glassware. In: C. Greenlaw (ed.): Late Antiquity. SOMA 2004: Symposium on Mediterranean Archaeology Proceedings of the Eighth Annual Meeting of Postgraduate Researchers. BAR. 1514. Dublin 2006, 123-130

= J. A. MLlward: Eurasian Crossroads. The History of Xinjiang. New York 2007.

南京市博物馆 NANJINGSHI BowUGUAN: 南京象山 5 号，6号， 7 号墓清理简报 Nanjing Xiangshan 5hao, 6hao, 7hao mu qingli jianbao. 文物 Wenwu 11 (1972) 23-42.

= 南京市博物馆 NANJING BOWUGUAN: 南京市郭家山东晋温氏家族墓 Nanjingshi Guojiashan Dong Jin Wenshijiazu mu. 考古 Kaogu 6 (2008) 383-505.

= 南京市博物馆 - 南京市云武区文化局 NANJINGSHI BowUGUAN-NANJINGSHI XUANWUQU WENHUAJU: 江苏南京市富贵山六朝墓地发掘简报 Jiangsu Nanjingshi Fuguishan mudu fajue jianbao. 考古 Kaogu 8 (1998) 35-47. 
NANJing DAXUE LishixiKAOGUZU 南京大学历史系考古组 1973

PREISER-KAPELlER 2014

PREISER-KAPELLER 2015

RÜTTI 1991

SELBITSCHKA 2010

SEVILLANO-LÓPEZ 2015

STERN-SCHLICK-NOLTE 1994

STERN 2001

DE LA VAISSIÈRE 2009

VON WALTER 2011

WANG-LU 2009

WANG 王 2011

WHITEHOUSE 1997

WHITEHOUSE 2001

WHITEHOUSE 2003

WHITEHOUSE 2005

WoOLF 1994

XinJIANG LoUlan KAOGUdUI 新疆楼兰考古队 1988

XINJIANG WewUERZIZHIQU BowUguAN 新疆维吾尔自治区博物馆-XINJIANG WENWU KAOGU YANJIUSUO 新疆文物考古研究所 2001

YING 2004

Yu 2004

YÜ 2008

YU 2010

Yu 2013
= 南京大学历史系考古组 NANJING DAXUE LISHIXIKAOGUZU: 南京大学北园东晋墓 Nanjing Daxue Beiyuan Dong Jin mu. 文物 Wenwu 4 (1973) 36-50.

= J. PREISER-KAPELLER: Peaches to Samarkand. Long distance-connectivity, small worlds and sociocultural dynamics across Afro-Eurasia, 300-800 CE. Draft for the workshop: "Linking the Mediterranean. Regional and Trans-Regional Interactions in Times of Fragmentation (300-800 CE)", Vienna, 11th-13th December 2014.

$=\mathrm{J}$. PREISER-KAPELLER: Harbours and maritime networks as complex adaptive systems $-\mathrm{a}$ thematic introduction. In: J. Preiser-Kapeller-F. Daim (eds): Harbours and Maritime Networks as Complex Adaptive Systems. RGZM-Tagungen 23. Mainz 2015, 1-24.

= B. RÜTTI: Die römischen Gläser aus Augst und Kaiseraugst. Forschungen in Augst 13.2 (1991)

= A. SelbitschKa: Prestigegüter entlang der Seidenstraße? Archäologische und historische Untersuchungen zu Chinas Beziehungen zu Kulturen des Tarimbeckens vom zweiten bis frühen fünften Jahrhundert nach Christus. Asiatische Forschungen 154. Wiesbaden 2010.

= D. Sevillano-López: Mitos y realidad en las descripciones del Imperio Romano en las fuentes chinas. In: N. C. Ramírez- J. de Miguel López (eds): Roma y el mundo mediterráneo: actas del I Congreso de Jóvenes Investigadores en Ciencias de la Antigüedad de la UAH, celebrado los días 5, 6 y 7 de marzo de 2014 en Alcalá de Henares. Alcalá 2015, 15-41.

= E. M. Stern-B. Schlick-Nolte: Early Glass of the Ancient World,1600 B.C. to A.D. 50: Ernesto Wolf Collection. Ostfildern: Gerd Hatje 1994.

= E. M. Stern: Römisches, byzantinisches und frühmittelalterliches Glas. 10 v. Chr.-700 n. Chr. Sammung Ernesto Wolf. Ostfilden 2001.

= É . DE LA VAISSIÈrE: The triple system of orography in Ptolemy's Xinjiang. In: W. Sundermann-A. Hintze-F. de Blois (eds): Exegisti monumenta: Festschrift in Honour of Nicholas Sims-Williams. Iranica 17. Wiesbaden 2009, 527-535.

= J. VON WALTER: Die Vorstellungen über das ostasiatische Ende der Seidenstraße in den antiken griechischen Quellen. In: J. Göbel-T. Zech (Hrsg.): Exportschlager - Kultureller Austausch, wirtschaftliche Beziehungen und transnationale Entwicklungen in der antiken Welt. München 2011, 86-106.

$=$ B. WANG-L. LU: Glass artifacts unearthed from the tombs at the Zhagunluke and Sampula cemeteries in Xinjiang. In: Gan F. (ed.): Ancient Glass Research Along the Silk Road 2009, 299-329

= 王志高 WANG ZHIGAO: 六朝墓葬出土玻璃容器漫谈——兼论朝鲜半岛三国时代玻璃容器的来 源 Liuchao Muzang chutu bolirongqi mantan - Jianlun Chaoxianbandao Sanguoshidai bolirongqide Yuanlai.南京博物院集刊 Nanjing Bowuyuan Jikan 12.1. (2011) 221-227.

= D. Whitehouse: Roman Glass in the Corning Museum of Glass. 1. New York 1997.

= D. WhitehousE: Roman Glass in the Corning Museum of Glass. 2. New York 2001.

= D. Whitehouse: Roman Glass in the Corning Museum of Glass. 3. New York 2003.

= D. Whitehouse: Sasanian and Post-Sasanian Glass in The Corning Museum of Glass. New York 2005.

$=\mathrm{G}$. Woolf: Becoming Roman staying Greek: culture, identity and the civilizing process in the Roman East. Proceedings of the Cambridge Philological Society 40 (1994) 116-143.

= 新疆楼兰考古队 XINJIANG LOULAN KAOGUDUI: 楼兰古城址调查与试掘简报 Loulangucheng Diaochayu Shijuejianbao. 文物 Wenwu 7 (1988) 1-22

= 新疆维吾尔自治区博物馆 XINJIANG WEWUERZIZHIQU BOWUGUAN-新疆文物考古研究所 XINJIANG WENWU KAOGU YANJIUSUO:中国新疆山普拉 — - - 古代于阗文明的揭示与研究 Zhongguo Xinjiang Shanpula---Gudai Yutianwenmingde Jieshiyu Yanjiu. 新疆民族出版社 Xinjiangminzuchubanshe 2001

$=\mathrm{L}$. YING: Ruler of the treasure country: the image of the Roman Empire in Chinese society from the first to the fourth century AD. Latomus 63.2. (2004) 327-339.

$=\mathrm{T}$. YU: A history of the relationship between the Western \& Eastern Han, Wei, Jin, Northern \& Southern Dynasties and the Western Regions. Sino-Platonic Papers 131 (2004) i-378.

= Y. YÜ: Han foreign relations. In: D. Twitchett-J. K. Fairbank (eds): The Cambridge History of China. 1: The Ch'in and Han Empires, 221 B. C.-A. D. 220. Cambridge 2008, 377-462.

$=\mathrm{Z}$. YU: Some thoughts on glass finds in the Tarim Oasis from the past ten years. In: B. Zorn-A. Hilgner (eds): Glass along the Silk Road from 200 BC to AD 1000. RGZM-Tagungen 9. Mainz 2010, 191-202.

$=$ T. Yu: China and the Ancient Mediterranean World. A survey of Ancient Chinese sources. SinoPlatonic Papers 242 (2013) 1-268. 


\section{APPENDIX}

CATALOGUE

CAT.I.1.

Name: fragments of a marbled ribbed bowl; Roman; Isings 1957, Form 3a; Rütti 1991, Form AR 2.1; Goethert-Polaschek 1977, Form $3 \mathrm{a} ; 1^{\text {st }}$ century $\mathrm{BC}-1^{\text {st }}$ century C.E.

Site: Shuangshan 双山 tomb no. 2, Ganquan 甘泉, Hanjiang 邗江县, Jiangsu Province 江苏;

Date: Eastern Han dynasty - 67 C.E.

Reference: NANIING BowUYUAN 南京博物元院 1981. Chemical analysis displayed in Gan 干 2005.

Description: two (in excavation report three) fragments, with deep purple and whitish marbled ribs. Casted; $2-3 \mathrm{~cm}$;

Localisation: a tunnel used by tomb raiders

Burial of: Guang Ling 广陵 $-9^{\text {th }}$ son of Guang Wudi 东汉光武帝;

Analogy: ribbed bowl from Jidd Hafs grave no. 36 in collection of the British Museum;

\section{CAT.I.2.}

Name: cup; Roman; Isings 1957, Form 96a var.; Rütti 1991, Form AR 60; Goethert-Polaschek 1977, 41/49a ; $2^{\text {nd }}-5^{\text {th }}$ century C.E.

Site: Laohudun 老虎墩, Ganquan 甘泉, Hanjiang 干江, Jiangsu Province 江苏;

Date: mid-late Eastern Han $-1^{\text {st }}-2^{\text {nd }}$ century C.E.

Reference: YangZhou BowUguan 扬州博物馆 1991. Chemical analysis displayed in BORELL 2010.

Description: nearly intact bluish transparent cup. Free-blown. Presumably everted mouth, cylindrical body, rounded base. Rim diameter: 7,8 cm; maximum height: $9,2 \mathrm{~cm}$;

Localisation: western side of main chamber

Burial of: head official or minister of Guang Ling or his generation

\section{CAT.II.1.1.}

Name: fragments of a cup; Roman;

Site: Qilundianjichang 汽轮电机厂 tomb no. 2; Eastern suburb of Nanjing;

Reference: NANJING BowUGUAN 南京市博物馆 1983. Chemical analysis displayed in NANJING BowUGUAN 南京博物馆 1983.

Date: Late/mid Eastern Jin - late/mid $4^{\text {th }}$ century;

Description: transparent yellowish fragments, altogether twenty-five pieces, with floral pattern composed of circles and ellipses on their surface. Presumably parts of a deep spherical cup. Maximum length: $5,5 \mathrm{~cm}$; width: $3 \mathrm{~cm}$; thickness: $0,2-0,5 \mathrm{~cm}$;

Location: a tunnel used by tomb raiders?

Burial of: Sima Dan 司马聑 [343-361], $5^{\text {th }}$ emperor of the Eastern Jin;

\section{CAT.II.1.2.}

Name: fragments; presumably Roman;

Site: Qilundianjichang 汽轮电机 $\Gamma$ tomb no. 2; Eastern suburb of Nanjing;

Reference: NANJING BowUGUAN 南京博物馆 1983. Chemical analysis displayed in NANJING BOWUGUAN 南京博物馆 1983.

Date: Late/mid Eastern Jin - late/mid $4^{\text {th }}$ century;

Description: one bluish opaque (?) fragment; Thickness: 0,1-0,3 cm;

Location: a tunnel used by tomb raiders?

Burial of: Sima Dan [343-361]; $5^{\text {th }}$ emperor of the Eastern Jin;

\section{$2 \mathrm{~cm}$}
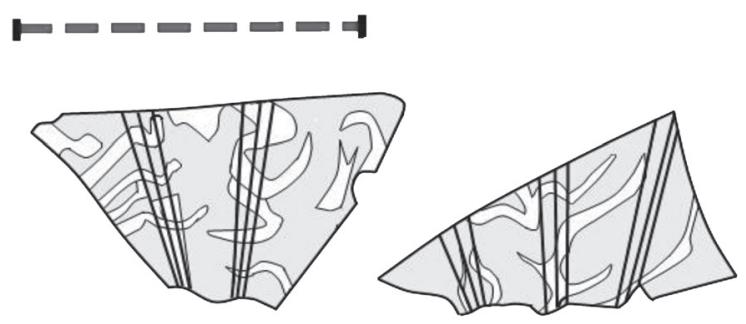

Fig. 9. Drawing of glass bowl from Ganquan Shuangshan (based on NANJING BOWUYUAN 南京博物元院 1981)

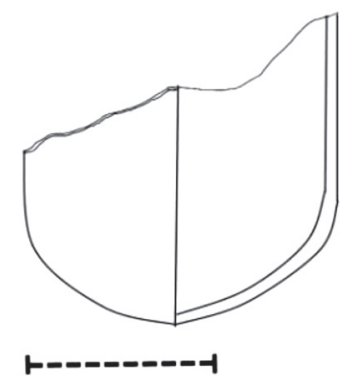

$5 \mathrm{~cm}$

Fig. 10. Drawing of the Laohudun glass cup (based on YANGZHOU BowUGUAN 扬州博物馆 1991) 
CAT.II.2.

Name: fragments of rim; presumably Roman;

Site: Northern Campus of Nanjing University 南京大学北园;

Reference: NANJING DAXUE LISHIXI KAOGUZU 南京大学历史系考古 组 1973.

Date: early Eastern Jin - early $4^{\text {th }}$ century

Description: fragments of a rim, presumably belonged to a hemispherical bowl with everted rim. Transparent, colourless glass. Decoration cut on wheel: single incised lines below lip and one band of oval facets. Estimated diameter of rim: $10 \mathrm{~cm}$; thickness: $0,1 \mathrm{~cm}$; Localisation: entrance corridor of sub-chamber, close to mainchamber;

Burial of: highly ranked aristocrat, member of the ruling family;

CAT.II.3.

Name: fragments of a deep bowl; presumably Roman;

Site: Shimenkan 石门坎乡, Nanjing city

Reference: LI 李-Tu 屠 1958 .

Date: early Six Dynasty- early $4^{\text {th }}$ century;

Description: fine decorated fragments of a deep bowl;

Localisation: central part of chamber;

Burial of: aristocrat;

CAT.II.4.1.

Name: beaker, presumably Sasanian;

Site: Xiangshan tomb no. 7; Nanjing city New Gate 新民们外的象山; Reference: NANJINGSHI BOWUGUAN 南京市博物馆 1972.

Date: early Eastern Jin - early $4^{\text {th }}$ century;

Description: intact, free-blown. Transparent, yellowish green with slightly everted mouth and rounded rim. Cylindrical body, base narrow and rounded. Pattern by two incised bands and oval facets under the lip, seven vertical facets on the body and bands and narrow oval facets on the bottom. Rim diameter $9,4 \mathrm{~cm}$, bottom diameter: $2,5 \mathrm{~cm}$, height: $10,4 \mathrm{~cm}$, thickness: $0,5-0,7 \mathrm{~cm}$;

Localisation: front of the male coffin;

Burial of: Wang Yi 王 or his relative - military officer, poet and calligrapher, kin of the ruling family;

Analogy: beaker from Amlash in the collection of the British Museum;

CAT.II.4.2.

Name: fragments; presumably Roman;

Site: Xiangshan tomb no. 7; Nanjing city New Gate 新民们外的象山; Reference: NANJINGSHI BOWUGUAN 南京市博物馆 1972.

Date: early Eastern Jin - early $4^{\text {th }}$ century;

Description: deep bluish fragments;

Localisation: front of female coffin, under the bronze jiadou [liquid container with three legs and a long handle];

Burial of: wife of Wang Yi or his relative;

CAT.II.5.

Name: hemispherical bowl; Sasanian? Roman?; Isings 1957, Form 96b; Rütti 1991, Form AR61; mid $2^{\text {nd }}-3^{\text {rd }}$ century;

Site: Fuguishan 富贵山 tomb no. 4; Nanjing city

Reference: NANJINGSHI BowUGUAN 南京市博物馆-NANJINGSHI XUANwUQu Wenhuaju 南京市玄武区文化局 1998.

Date: late Eastern Jin - end of the $4^{\text {th }}$ century;

Description: intact, free-blown. Transparent bluish with spherical body. Mouth outsplayed, rounded rim, wall descends in steep S-shaped curve. Base slightly concave. On lower part of wall and base twenty
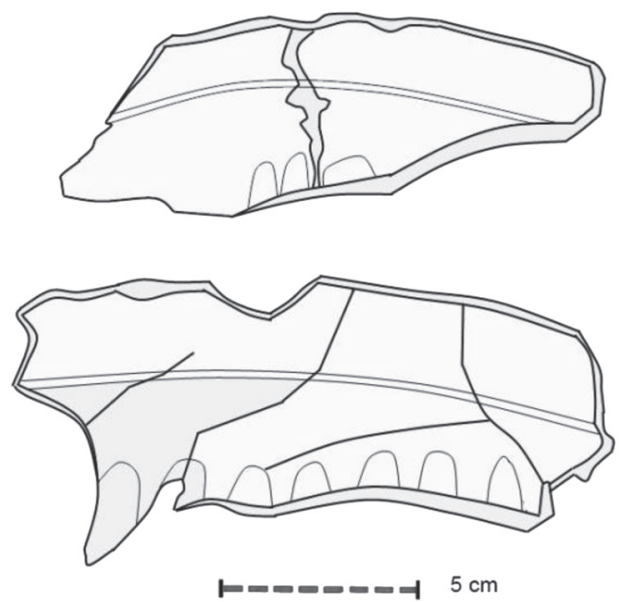

Fig. 11. Drawing of glass fragments from the Northern Campus of Nanjing University (based on NANJING DAXUE LISHIXI KAOGUZU 南京大学历史系考古组 1973)

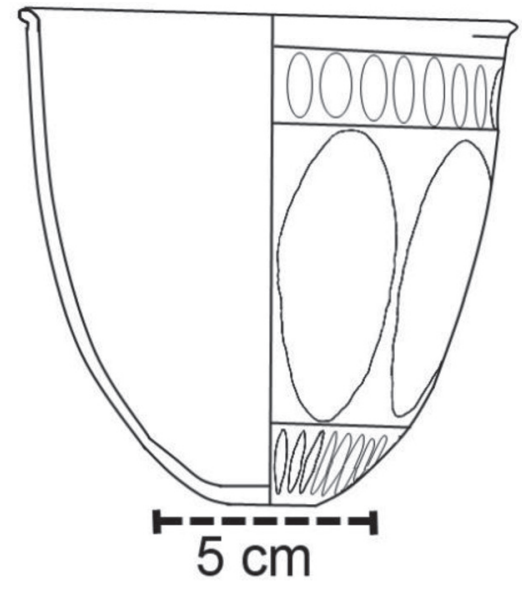

Fig. 12. Drawing of glass bowl from Xiangshan (based on AN 安 2000)

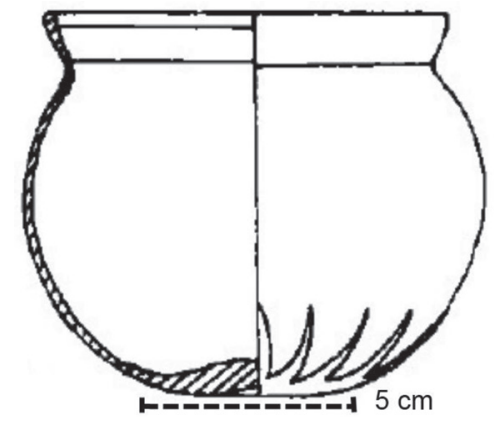

Fig. 13. Drawing of glass bowl from Fuguishan (based on NANJINGSHI BOwUGUAN 南京市博物馆-NANJINGSHI Xuanwuqu Wenhuaju 南京市玄武区文化局 1998) 
short ribs made by pinching. Rim diameter: $8,5 \mathrm{~cm}$; height: $7,8 \mathrm{~cm}$; thickness at rim $0,02-0,03 \mathrm{~cm}$, at bottom: $0,5 \mathrm{~cm}$;

Localisation: front part of the chamber;

Burial of: member of the ruling family;

\section{CAT.II.6.}

Name: deep bowl; presumably Roman; Isings 1957, Form 96b1; Rütti 1991, Form AR60/1B;second part of the $2^{\text {nd }}$ century $-4^{\text {th }}$ century;

Site: Xianheguan 仙鹤观 tomb no. 6; Eastern suburb of Nanjing

Reference: NANJING BOWUGUAN 南京博物馆 2000.

Date: mid-late Eastern Jin - second half of the $4^{\text {th }}$ century;

Description: intact transparent bowl. Mouth outsplayed with lip cracked off and ground. Spherical body and round bottom. Decoration by two incised bands under rim, vertical oval facets with incised band on the body, and horizontal and vertical facets on bottom. Rim diameter: $9,1 \mathrm{~cm}$; height: $7 \mathrm{~cm}$; thickness: $0,1-0,15 \mathrm{~cm}$;

Localisation: near female coffin;

Burial: Gao Kui 高悝 and his wife - head minister of administration during Eastern Jin;

Analogy: Roman from Karanis (27/C 54 E/01 Mich. 6193)?

\section{CAT.III.1.}

Name: fragment of faceted glass cup (80LBC:180A); Roman

Site: Xinjiang-Uyghur Autonomous Region 新疆维吾尔自治区, Loulan 楼兰古城 site LA;

Reference: XINJIANG LOULAN KAOGUDUI 新疆楼兰考古队 1988. Chemical analysis displayed in Li 李-GAN 干-ZHANG 张 2007, 153. Date: uncertain; $4^{\text {th }}$ century?

Description: transparent, whitish fragment of a cup with everted mouth. Two incised lines under the rim, and decoration of amorphous rhomboid facets. Maximum length 5,6 cm; thickness $0,2 \mathrm{~cm}$; at the rim $0,4 \mathrm{~cm}$;

Localisation: near the settlement;

Analogy: no. MG 21425 faceted bowl from Begram;

\section{CAT.III.2.}

Name: blue eye bead (84HLSM49:155L); Roman;

Site: Xinjiang-Uyghur Autonomous Region 新疆维吾尔自治区, Shanpula 山普拉 cemetery no. I. grave no. 49;

Reference: XINJIANG WEWUERZIZHIQU BOWUGUAN 新疆维吾尔自治 区博物馆-XINJIANG WENWU KAOGU YANJIUSUO 新疆文物考古研究 所 2001. Illustration in Gan 干 2007. 图 9. Chemical analysis displayed in LI 李-GAN 干-ZHANG 张 2007. 153.

Date: Eastern Han Dynasty $-1^{\text {st }}-2^{\text {nd }}$ century

Description: opaque, rounded eye bead; blue with blue and white concentric decoration. Height $0,6 \mathrm{~cm}$; diameter $0,6 \mathrm{~cm}$;

Localisation: on a necklace of orange beads; unearthed from a mass grave of 16 bodies;
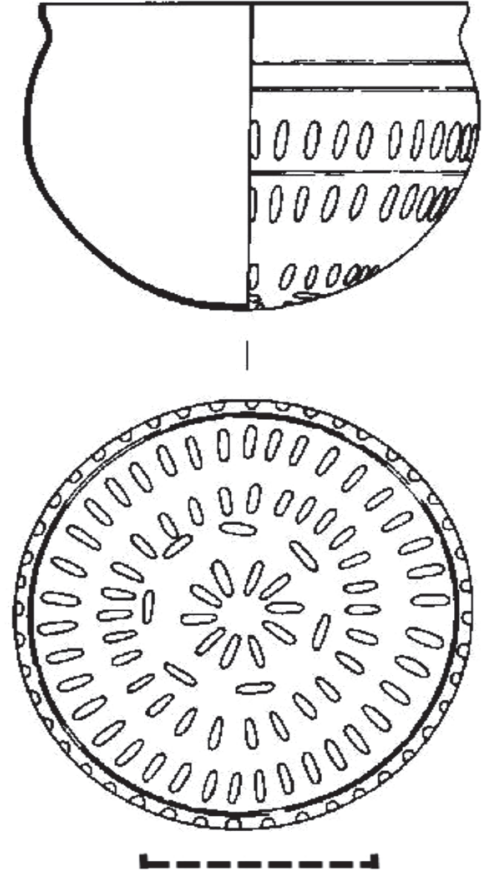

Fig. 14. Drawing of glass bowl from Xianheguan (based on NANJING BOWUGUAN 南京博物馆 2000)

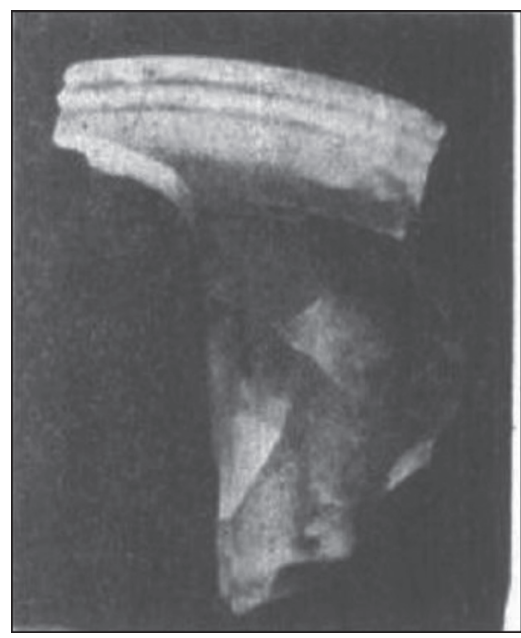

Fig. 15. Original photo of the Loulan glass cup published in the archaeological report

(XINJIANG LOULAN KAOGUDUI 新疆楼兰考古队 1988)

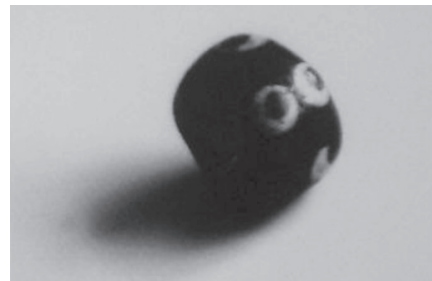

Fig. 16. Glass bead from Shanpula (GAN 干 2007, 图 9) 